\title{
RESISTANSI DAN MODEL RESISTANSI \\ DALAM NOVEL PEREMPUAN BERKALUNG SORBAN \\ KARYA ABIDAH EL KHALIEQY
}

\section{RESISTANCE AND THE MODEL OF GENDER EQUALITY IN PEREMPUAN BERKALUNG SORBAN BY ABIDAH EL KHALIEQY}

\author{
Wildan \\ Fakultas Sastra dan Budaya, Universitas Khairun \\ Jalan Kampus, Kelurahan Gambesi, Ternate Selatan \\ Telepon: 085256243375, Pos-el: wildanmattara@gmail.com
}

\begin{abstract}
The research on "Perempuan Berkalung Sorban" aimed at revealing aesthetic reconstructive model of gender discrimination in an Islamic boarding school environment and the model of aspired gender equality. This research used feminist literary criticism as a medium to express gender equality in the novel "Perempuan Berkalung Sorban". Feminist literary criticism is regarded as a new life in a critique based on feelings, thoughts, and responses of the women based on the role vision and position in the literary world. Through the theory of feminist literary criticism, it could be concluded that the resistance and the model of gender equality in the novel 'Perempuan Berkalung Sorban' is a structured and massive gender discrimination which was built up from internal and external elements of literary works, such as the use of age, situation of the house, school and marriage. Meanwhile, Islam has been used as a shelter for the establishment of patriarchal culture in the different spheres of life. The model of gender equality was finally shown through Nisa's second marriage with Khodori Lek. Nisa's marriage was a marriage which became an ideal or aspired model of gender equality and a form of resistance to the first marriage with Syamsuddin.
\end{abstract}

Keywords: gender discrimination, resistance, and resistance model

\begin{abstract}
Abstrak
Penelitian ini bertujuan untuk mengungkapkan rekonstruksi estetis diskriminasi gender dalam lingkungan pesantren dan model kesetaraan gender. Penelitian ini menggunakan kritik sastra feminis sebagai media pendekatan untuk mengungkapkan resistansi dan model resistansi. Kritik sastra feminis dianggap sebagai kehidupan baru dalam kritik berdasarkan perasaan, pikiran, dan tanggapan dari para perempuan berdasarkan penglihatan terhadap peran dan kedudukannya dalam dunia sastra. Melalui teori kritik sastra feminis dapat disimpulkan bahwa resistansi dan model resistansi dalam novel Perempuan Berkalung Sorban (PBS) merupakan peristiwa diskriminasi gender yang telah terjadi secara terstruktur dan masif yang dibangun dari unsur dalam dan luar karya sastra, yaitu pemanfaatan usia, latar dalam lingkungan rumah, sekolah, dan perkawinan.Sementara itu, agama Islam telah dimanfaatkan sebagai tempat berlindung bagi kemapanan budaya
\end{abstract}


patriarkal dalam berbagai ranah kehidupan. Model kesetaraan gender akhirnya ditunjukkan melalui perkawinan kedua Nisa dengan Lek Khudori. Perkawinan Nisa ketika dewasa tersebut adalah perkawinan yang menjadi model kesetaraan gender yang diidealkan atau yang dicita-citakan yang menjadi bentuk resistansi terhadap perkawinannya yang pertama dengan Syamsuddin.

Kata kunci: diskriminasi gender, resistansi, dan model resistansi

\section{Pendahuluan}

Novel PBS (2004) karya Abidah El Khalieqy termasuk salah satu novel kontroversial dalam masyarakat pembaca sastra Indonesia. Sejumlah tanggapan muncul dari kalangan masyarakat, termasuk ormas Islam, sebab materi teks novel ini dianggap sangat radikal. Melalui PBS, pesantren dianggap masih sangat kuat menganut budaya patriarkat yang bertolak belakang dengan program pendidikan nasional yang berusaha menciptakan lembaga pendidikan yang berkesetaraan gender. Gejala ini sekaligus kontraproduktif dengan simbol pesantren sebagai lembaga pendidikan Islam yang menjadi tempat untuk memperoleh bimbingan akhlak (kebenaran dan keadilan).

Kontroversi PBS makin menajam ketika ditransformasi ke layar lebar (bioskop) dan menjadi salah satu pilihan berita oleh televisi swasta (TV One) pada tahun 2009. Tanggapan masyarakat (Ormas Islam, FPI) yang cukup keras tentu dapat dimaklumi dan sangat wajar mengingat sensitivitas kelompok masyarakat pada ideologi yang diyakininya, yang menjadi sumber kebenaran mutlak, sedang diusik oleh kehadiran PBS. Terlebih lagi, ketika pesantren yang menjadi sumber peradaban budaya dan tempat pendidikan Islam yang dipercaya dapat mendidik dan membina anak bangsa untuk menjadi manusia yang bertakwa kepada Tuhan dicitrakan sebagai tempat tumbuh-kembangnya budaya patriarkat.

Abidah El Khalieqy, melalui PBS, dianggap telah menjatuhkan martabat, harga diri, dan membuka aib dunia pendidikan Islam di Indonesia, khususnya pesantren. Namun, di lain sisi, tentu gejala ini juga tidak dapat diabaikan mengingat karya sastra bagian dari manivestasi suatu budaya masyarakat, termasuk dalamkehidupan pesantren. Dengan memanfaatkan kualitas manipulatif medium bahasa (nilai estetika) karya sastra, menurut Ratna (2003: 35), bahkan dapat menunjukkan maksud yang sama sekali bertentangan. Meskipun demikian, karya sastra memiliki tujuan akhir yang sama, yakni sebagai motivator ke arah aksi sosial yang lebih bermakna, sebagai pencari nilai-nilai kebenaran yang dapat mengangkat dan memperbaiki situasi dan kondisi alam semesta. Kreativitas seni sastra bukan aktivitas yang otonom, bukan pula proses kognitif yang berada di luar hubungan-hubungan sosial. Proses kreatif sebagai rekonstruksi materialisme kultural dipersiapkan oleh dimensi ruang dan waktu tertentu, dan dengan sendirinya diarahkan oleh asumsi-asumsi sosial historis universum tersebut (Ratna, 2004: 39).

Dalam PBS, resistansi dan diskriminasi gender dimetaforkan dan direkonstruksi melalui perjalanan hidup Nisa yang digambarkan sejak masih berumur tujuh tahun hingga pada kegagalannya membina rumah tangga. Resistansi sebagai akibat diskriminasi dimulai dari pesantren, lingkungan rumah, hingga pada pernikahannya yang masih di bawah umur, 15 tahun. Resistansi Nisa sangat menohok ibu, kedua kakak laki-laki, dan bapaknya yang dikenal sebagai kiai populer di kampung. Dalam konteks ini, resistansi yang dilakukan Nisa tentu bukan karena memiliki rasa benci kepada keluarga, melainkan untuk menunjukkan ketidakmapanan budaya patriarkal.

Di rumah, Nisa hanya bekerja dalam ranah domestik sehingga tidak punya waktu belajar yang cukup, sedangkan kedua kakak laki-lakinya, yang juga berada dalam rumah yang sama, lebih banyak bersantai. Bahkan, mereka tidak bekerja sebagaimana Nisa bekerja untuk kepentingan orang dirumah. Padahal, keduanya memiliki hak yang sama untuk belajar dan tidur yang cukup. Begitu juga di sekolah, Nisa berhadapan dengan guru yang selalu memberikan contoh dan memetakan wilayah kerja antara lakilaki dan perempuan, misalnya suami bekerja di kantor, sedangkan ibu bekerja di rumah. Oleh Nisa, pernyataan seperti ini tidak dapat diterima dan dianggap salah karena tetangga rumahnya menunjukkan fakta lain. Istri bekerja di kantor, sedangkan suami meng- 
urus burung piaraan dirumah. Aktivitas kognitif Nisa yang berkembang secara tidak normal oleh pembelajaran yang tidak sehat telah mendorong untuk selalu bertanya, termasuk kepada keluarga yang dianggap sebagai tempat memperoleh keadilan yang paling arif dan bijak. Akan tetapi, jawaban yang diterimanya hanya menjadi sekumpulan pertanyaan yang tidak pernah memuaskan yang membuatnya makin kecewa.

Pembelajaran diskriminasi gender yang diperoleh Nisa secara terpola menunjukkan bahwa terdapat sebuah konstruksi sosial yang sudah mapan terhadap diskriminasi kepada perempuan. Perbedaan gender antara laki-laki dengan perempuan, terjadi melalui proses yang panjang. Demikian juga, adanya perbedaan-perbedaan gender disebabkan oleh banyak hal, di antaranya dibentuk, disosialisasikan, diperkuat, bahkan dikonstruksikan secara sosial dan kultural melalui ajaran keagamaan dan negara. Melalui proses panjang, sosialisasi gender tersebut akhirnya dianggap menjadi ketentuan Tuhan- (Fakih, 2001: 9)

Upaya resistansi yang didorong oleh ketimpangan gender, juga sekaligus menunjukkan adanya rekonstruksi model diskriminasi gender. Model yang direkonstruksi melalui pemanfaatan usia tokoh, yaitu usia anak-anak, remaja, hingga dewasa. Model rekonstruksi ini, sebenarnya untuk menunjukkan bagaimana hegemoni kaum patriarkat atas kaum perempuan tersosialisasikan secara formal dan mapan, baik di lingkungan rumah maupun di lingkungan sosial.

Merujuk pada rekonstruksi model dan fenomena perlawanan perempuan dalam novel PBS, maka telah mendorong dilakukannya penelitian ini. Selain itu, novel ini juga dianggap telah menyita perhatian publik, yang berarti, banyak menyimpan, atau setidaknya mengandung nilai-nilaikesetaraan gender yang terabaikan yang dianggap patut dan menarik untuk diteliti. Pada konteks ini, penelitian akan difokuskan pada resistansi perempuan dan model resistansi.

\section{Kerangka Teori}

\subsection{Ragam Aliran dan Studi Kritik Sastra Feminis}

Inti pergerakan feminis adalah meningkatkan kedudukan dan derajat perempuan agar sama atau seja- jar dengan kedudukan laki-laki. Pergerakan ini muncul karena inferioritas atau kedudukan dan derajat perempuan telah dipandang rendah. Secara diskriminatif(Djajanegara, 2000: 28), perempuan harus menjaga kesalehan dan kemurnian mereka, bersikap pasif dan menyerah, rajin mengurus keluarga dan rumah tangga atau menjaga domestisitas, telah mendorong lahirnya gerakan feminis. Nilai-nilai ini dianggap telah menghambat perkembangan wanita untuk menjadi manusia seutuhnya. Tingginya kesadaran atas keinginan untuk membangun kritik sastra feminis berdampak terhadap munculnya banyak ragam jenis kritik sastra feminis.

1. Keritik sastra feminis (kritik ideologis). Kritik sastra ini melibatkan wanita, khususnya kaum feminis sebagai pembaca. Yang menjadi pusat perhatian pembaca wanita adalah citra serta stereotipe wanita dalam karya sastra.

2. Kritik (ginokritik) yang fokus pada penulis-penulis wanita, termasuk sejarah karya sastra wanita, gaya penulisan, genre, dan struktur tulisan wanita. Penelitian fokus pada perbedaan, seperti perbedaan tulisan wanita dengan laki-laki.

3. Kritik sastra feminis-sosialis, meneliti tokoh-tokoh wanita dari sudut pandang sosialis, yaitu kelas-kelas masyarakat.

4. Kritik sastra feminis-psikoanalisis diterapkan pada tulisan wanita. Para feminis berpendapat bahwa pembaca wanita biasanya mengidentifikasi dirinya dengan atau menempatkan dirinya pada si tokoh wanita, sedangkan tokoh wanita tersebut pada umumnya merupakan cermin penciptaannya.

Pada dasarnya ragam kritik sastra feminis merupakan cara menafsirkan suatu teks, yaitu dalam studi karya sastra, kritik sastra feminis digunakan sebagai materi atau alat pergerakan kebebasan perempuan dan tempat menyosialisasikan ide feminis. Sistemkerja kritik sastra feminis, adalah meneliti karya sastra dengan melacak ideologi yang membentuknya dan menunjukkan perbedaan-perbedaan yang dikatakan oleh karya dengan yang tampak dari sebuah pembacaan yang diteliti. Kritik sastra feminis bertujuan mengakhiri dominasi pria dan berusaha mengambil peran sebagai suatu bentuk kritik negosiasi, bukan 
sebagai bentuk konfrontasi. Dengan kata lain, kritik ini dilakukan dengan tujuan untuk menumbangkan wacana-wacana dominan, bukan untuk berkompromi dengan wacana dominan tersebut (Ruthven dalam Sofia, 2009: 21).

Kesadaran terhadap ketakadilan kesetaraan gender yang dialami oleh perempuan sebenarnya telah mulai terlihat pada karya-karya penulis Muslimah pada akhir abad ke-19 pertengahan abad ke-20, baik dalam bentuk puisi, cerita pendek, novel, esai, artikel, buku, maupun dalam bentuk memoar pribadi atau kumpulan surat (Drajat, 2003:2).

Tentu semua itu merupakan aksi-aksi sosial yang mengindikasikan adanya diskriminasi gender yang menjadi bagian dari konstruksi sosial yang dibungkus melalui agama. Studi mengenai feminisme dan agama selalu melahirkan berbagai kontroversi sebab studi feminisme dan agama selalu melibatkan seperangkat sistem emosional, yaitu paham yang saling bertentangan yang berpengaruh langsung kepada kehidupan manusia. Di satu sisi, emosi keimanan sangat kuat menjaga tradisi agama yang diwarisi dari generasi kegenarasi. Di sisi lain, semangat dekonstruksi terhadap tradisi patriarkal dalam pelaksanaan ajaran agama menjadi corak pemikiran feminisme. Dalam hal ini, semangat dekontruksi feminisme dituntut untuk melihat relasi gender dalam tradisi agama secara objektif.

Gross dalam penelitian Rita M. menyimpulkan bahwa dalam konteks tertentu, tradisi agama — seperti Islam - memperkuat dukungan terhadap eksistensi perempuan, tetapi dalam manifestasi yang lain dipenuhi dengan semangat patriarki. Kesimpulan Rita M. Gross memiliki kesamaaan paradigmatis dengan pandangan Khaterine K Young yang menyatakan bahwa terdapat kecenderungan yang relatif sama dalam tradisi agama-agama tentang dominasi lakilaki atas perempuan. Tradisi tersebut telah menggiring penganut agama untuk menempatkan laki-laki di ruang publik dan perempuan di ruang domestik (Kadarusman, 2005: 1--2).

Gramatika, Volume II, Nomor 2, Juni-Desember 2014

\subsection{Diskriminasi Perempuan dalam Pesantren: Dasar Kreativitas Seni dalam Konteks Fakta Sosial}

Hampir seluruh karya sastra, baik yang dihasilkan oleh penulis pria maupun wanita, dominasi pria selalu lebih kuat. Figur pria terus menjadi prioritas (the authority sehingga mengasumsikan bahwa wanita adalah impian. Wanita selalu diposisikan sebagai wanita kelas dua (the second sex), warga kelas dua, dan tersubordinasi. Atas dasar itu, penelitian sastra ditantang untuk menggalilebih jauh konstruksi gender dalam sastra dari waktu ke waktu (Endraswara, 2008: 143). Reaktualisasi kehidupan ini secara estetis digambarkan dalam kehidupan pesantren-dijadikan sebagai sarana dan media pembelajaran pendidikan berbasis agama Islam. Dalam pesantren, selain mendalami ilmu agama Islam, para santri dan santriwati mempraktikkan secara sosial pengetahuan agama melalui media pemondokan yang mencerminkan miniatur praktik kehidupan sosial yang Islami. Pembelajaran pada dua aspek kehidupan ini merupakan bangunan keseimbangan antara ilmu dan praktik (dunia dan akhirat) sehingga keterlibatan para kiai menjadi sangat penting. Kiai adalah orang sangat dihormati dan disegani karena dianggap sebagai sumber pengetahuan yang memiliki pengetahuan luas tentang ilmu agama,"malaikat" yang dapat menjadi pengadil dan penumbuh rasa tenteram dalam lingkungan masyarakat.

Dalam konteks inilah pesantren dengan segala simbol dan perannya dalam masyarakat menjadi sumber inspirasi kreativitas seni. Namun, dalam PSB, pesantren dan kiai bukan menjadi tempat pemerolehan rasa adil (kesetaraan gender); pengadil pada semua ranah kehidupan yang berhubungan dengan peran sosial antara laki-laki dan perempuan.

Sebagai aktivitas kehidupan budaya, kehidupan ini tidak dapat dihindari untuk menjadi awal atau dasar permulaan ekspresi estetik penciptaan karya sastra. Artinya, aktvitas pendidikan yang diskriminatif di pesantren ini, juga sudah menjadi salah satu dari berbagai bentuk representasi budaya yang menggambarkan relasi dan rutinitas gender. Selain itu, teks sastra juga dapat memperkuat dan membuat stereotipe gender baru yang lebih merepresentasikan 
kebebasan gender. Oleh karena itu, kritik sastra feminis membantu membangun studi gender yang direpresentasikan dalam karya sastra.

\section{Metode Penelitian}

Penelitian ini menggunakan metode penelitian kualitatif-deskriptif, yaitu metode yang menganggap bahwa objek penelitian bukan gejala sosial sebagai bentuk substantif, melainkan makna-makna yang ada di balik tindakan, yang justru mendorong timbulnya gejala sosial. Selain itu, deskriptif diperlukan untuk menguraikan dan menjelaskan subjek yang diamati sebagai data dan fakta hasil penelitian.

\subsection{Sumber Data}

Penelitian ini merupakan kajian pustaka dan menggunakan kritik sastra feminis sebagai media pendekatan. Objek penelitian adalah novel "Perempuan Berkalung Sorban" karya Abidah E1 Khalieqy dengan data sekunder yang diperoleh dari berbagai studi pustaka, yang bersifat menunjang data penelitian, seperti buku-buku umum yang berkaitan dengan objek kajian yang sedang diteliti. Semua data sekunder dipakai untuk menunjang analisis data primer.

\subsection{Teknik Pengumpulan Data}

Pengumpulan data dilakukan dengan menggunakan sistem kartu (teknik tabulasi), cara ini berfungsi untuk mengidentifikasi dan mengklasifikasi data yang ada dalam novel "Perempuan Berkalung Sorban", sekaligus melakukan pencatatan secara kontinyu terhadap data yang menjadi sumber data.

\section{Pembahasan}

\subsection{Resistansi dan Model Resistansi Perempuan pada Usia Anak-Anak}

Judul novel Perempuan Berkalung Sorban, sudah menunjukkan adanya ketegasan resistansi. Dalam gaya ironi, Perempuan Berkalung Sorban (kata baku: serban) dapat dimaknai dalam bahasa sederhana bahwa "kalau lelaki dapat berkalung serban, mengapa tidak bagiperempuan?' Dalam konteks sosial, serban adalah penunjuk laki-laki, pemimpin agama, dan bahkan kekuasaan. Artinya, dengan segala pem- berian makna itu juga dapat disandangkan kepada kaum perempuan (kalung serban). Begitu juga desain sampul, desain tokoh Nisa ditampilkan berserban yang berlawanan arah dengan foto perempuan lainnya yang tunduk pada aturan lelaki (menggunakan mukena). Artinya, semua perempuan tunduk pada aturan konstruksi laki-laki, tetapi Nisa membangkang dan melakukan perlawanan (membelakangi semua orang, tidak searah) yang digambarkan melalui serban yang dikalungkan di leher.

Novel PBS merupakan cerminan bagi sebagian perempuan-kalau tidak dapat dikatakan keseluruhan-, bahwa masih banyak diskriminasi yang dialami oleh kaum perempuan hingga saat ini, baik sebagai seorang anakmaupun sebagai seorang istri. Dalam novel PBS, sejak berusia anak-anak hingga dewasa, seorang perempuan digambarkan sepak terjangnya membela hak-haknya atas dominasi kaum laki-laki. Namun, di balik resistansi itu, juga ternyata menunjukkan adanya model, yaitu pemanfaatan usia sebagai model, yang tidak hanya menunjukkan upaya resistansi, tetapi juga sekaligus penunjukkan adanya ruang kehidupan hegemoni laki-laki atas kaum perempuan yang secara konspiratif sudah terbangun mapan.

Sebagai gaya, model estetik pengungkapan kemapanan konspiratifatas diskriminasi gender digambarkan melalui peristiwa diskriminasi dan resistansi yang dilakukan Nisa yang masih berusia usia anakanak, yaitu anak perempuan yang melakukan resistansi dalam lingkungan keluarga dengan harapan dapat memperoleh perlakuan yang sama dengan saudaranya yang berjenis kelamin laki-laki dari kedua orang tuanya. Peristiwa model resistansi dapat dilihat ketika dalam keadaan santai terjadi gurau antara Nisa dengan kedua kakaknya, yaitu Risal dan Wildan. Akan tetapi, peristiwa itu mengusik Nisa karena bagian akhir dari gurauan itu, jika tidak dijawab, Nisa akan dianggap sebagai perempuan bodoh-lazimnya anak-anak bersenda gurau.

"Aku merenung sejenak, kalau aku tak bisa menemukan jawabannya dia pasti akan mengejekku.Mencibirku sebagai anak perempuan yang bodoh, aku tahu bedanya.Apa? Ayo katakan" yang satu binatang, satunya manusia" 
“Tapi kan sama-sama perempuan". Jawab kakakku dengan lantang, sambil meletakkan telunjuk jari tangannya di atas hidung, (PBS, hlm. 3)

Percakapan santai, tetapi dalam suasana batin yang menjengkelkan, itulah yang dialami dan memaksaNisa berusaha menjawab pertanyaan kakaknya. Jawaban Nisa tidak lain adalah untuk menegaskan bahwa dirinya tidak bodoh sepertiyang dibayangkan kedua kakaknya. Namun, jawaban Nisa tidak mendapat tanggapan yang serius dari Rizal dan Wildan. Bagi Rizal jawaban itu hanya mengada-ada sehingga memberikan isyarat gerak tubuh kepada Nisa dengan jari yang menunjuk ke hidung. Muatan diskriminasi yang merendahkan perempuan pada konteks ini adalah meletakkan jari telunjuk di atas hidung yang bermakna perempuan (Nisa) tidak menggunakan akal untuk berpikir, tetapi menggunakan indera penciuman. Pengertian lain atas peristiwa ini adalah bahwa pada usia yang masih sangat belia, anak-anak (laki-laki) sudah dibentuk oleh keluarga dan lingkungannya untuk mendiskreditkan kaum perempuan dalam soal kecerdasan.

Dialog yang menggambarkan sikap resistansi Nisa terhadap diskriminasilaki-laki dapat dilihat pada kutipan berikut.

"Bagaimana Nisa? Apa yang kau tanyakan tadi?"

"Kakak saya pernah bilang, katanya mereka sedang membicarakan urusan laki-laki.Apa ke kantor itu termasuk urusan laki-laki, Pak Guru?"

"Tetapi ibunya Dita juga pergi ke kantor pak guru, dan tidak pernah ke pasar."

"Oya?Siapa itu Dita? Temannya Nisa?"

"Tetangga saya, pak"

"Baik-baik anak-anak memang ada seorang ibu yang juga pergi ke kantor, mungkin karena suaminya meninggal sehingga ibu harus mencari nafkah sendiri untuk...."

“Tetapi ayahnya Dita belum meninggal, Pak. Ayahnya Dita memiliki banyak burung dan setiap harinya memberi makan burung dan mengajarinya kalimat ... rejeki nomplok, rejeki nomplok" (PBS, hlm. 11).

Pada peristiwa itu dengan tegas ditunjukkan adanya kegamangan oleh guru untuk menanggapi pernyataan Nisa yang polos. Pada konteks ini ada upaya untuk melakukan kebohongan terhadap keberatan Nisa dengan mencoba menutupi kenyataan yang dilihat Nisa di tetangga rumahnya bahwa lakilaki tidak berurusan dengan kantor, tetapi mengurus burung di rumah. Pada peristiwa ini Nisa mengharapkan agar gurunya terbuka dan jujur, bahwa tidak selamanya yang bekerja di kantor adalah laki-laki. Apa yang disaksikan Nisa tidak terlepas dari rasa senang bermain dan ingin berbagi atas pengalaman yang diterimanya. Dengan pengalaman bermainnya Nisa berusaha menunjukkan fakta yang berbeda dengan yang disampaikan gurunya. Pengalaman Nisa menunjukkan bahwaperempuan juga menjinjing tas ke kantor, sedangkan yang menjaga anak di rumah adalah seorang laki-laki. Begitu juga dengan ayah Dita, hanya mengurus burung piaraan di rumah.

Sikap resistansi Nisa pada peristiwa tanya jawab dengan guru dalam kelas setidaknya menunjukkan dua hal. Pertama, resistansi itu sendiri, dan kedua pemanfaatan usia yang dimulai pada usia anak-anak sebagai model resistansi yang menegaskan (permulaan) adanya kemapanan hegemoni laki-laki atas perempuan yang sudah sejak lama terbangun secara sistematis dari suatu lingkungan budaya melalui kalimat-kalimat yang bias gender. Lanjutan fenomena ini akan dijelaskan pada pemindahan pola penceritaan dari pemanfaatan usia anak-anak ke usia dewasa.

Kutipan berikutnya yang menunjukkan sikap resistansi terhadap perlakuan berbeda yang diterima Nisa dengan Risal dan Wildan dapat dilihat pada percakapan Nisa dengan pamannya yang selalu memberi motivasi untuk belajar agar maju wawasan dan cerdas berpikir, sebagai berikut.

"Tapi aku ingin belajar naik kuda dan pergi ke kantor."

"Apa hebatnya naik kuda dan apa enaknya pergi ke kantor, Nisa?"

"Jika aku naik kuda, semua orang mendongak ke arahku.Aku juga bisa memimpin pasukan perang seperti Aisyah atau putri Budur sehingga para laki-laki perkasa menjadi tunduk di belakangku. Dan jika aku pergi ke kantor, bajuku wangi dan rapi tidak seperti lek Sumi yang seharian di dapur, badannya bau dan bajunya kedodoran" (PBS, hlm. 15). 
Sikap resistansi Nisa pada peristiwa di atas menunjukkan bahwa Nisa (perempuan) juga dapat menjadi penguasa dan pemimpin yang perkasa, sebagaimana laki-laki dapat melakukannya (kemampuan menunggang kuda). Jika belajar dengan sungguhsungguh, semua itu dapat diraih. Dengan demikian, laki-laki tidak akan lagi merendahkan Nisa (perempuan), apalagi menganggap bahwa pekerjaan perempuan hanya dalam wilayah domestik.

Pada peristiwa resistansi yang lain, membangun kepercayaan atas kemampuan yang dimiliki perempuan, juga tidak akan diperoleh, selama bagian dari nikmat bersumber darikekuasaan laki-laki. Oleh karena, laki-laki akan selalu menjadi pemenang karena dimenangkan oleh kekuatan asumsi paham maskulinisme, oleh ayat-ayat atau hadis-hadis yang belum tentu tafsirannya terbebas darikepentingan lakilaki. Yang membuat lelaki selalu merasa menguasai perempuan adalah masyarakat itu sendiri yang dibangun mulai dari aturan-aturandi rumah hingga kalimat-kalimat yang bernuansa mendiskriminasi perempuan. Kutipan yang mencerminkan diskriminasi dapat dilihat pada perisitiwa, berikut.

“Apa benar, Mbak May? Jika sekarang Nisa belajar mencuci, memasak, menyapu, apa masa depan Nisa terjamin? Dan jika Wildan dan Risal enak-enakan tidur di kamar, apa masa depan mereka juga terjamin? (PBS, hlm. 21).

Pada dasarnya apa yang menjadi tugas Nisa dan pembiaran perilaku kepada kedua kakanya adalah dua aktivitas yang sama-sama tidak dapat menjamin kebahagiaan Nisa dan kakaknya di masa yang akan datang. Oleh karena itu, yang ingin ditegaskan oleh Nisa pada kutipan tersebut adalah tidak perlu ada perlakuan yang berbeda (antara Nisa dan kedua kakaknya) kalau perbedaan itu juga tidak memberi jaminan masa depan yang lebih baik. Nisa sebagai anak-anak juga membutuhkan kebebasan untuk bermain; menikmati masa kecilnya dengan gembira, tanpa dibebani dengan sejumlah kewajiban domestik, seperti mencuci piring, memasak di dapur, menyapu, dan membersihkan halaman rumah. Sementara itu, kedua kakaknya yang memiliki tenaga yang lebih kuat tidak dibebani kewajiban apapun di rumah.
Perlakuan diskriminasi makin menyedihkan karena sikap Nisa yang berupaya menunjukkan perilaku kesataran gender oleh kedua orang tuanya dianggap sebagai sikap yang membandel. Jadi, selain dinomorduakan dalam perlakuan, juga dianggap sebagi anak yang nakal, yaitu anak yang suka membantah aturan atau perintah orang tua-status orang tua menjadialat untuk melindungi budaya patriarkal. Perasaan kasih sayang orang tua yang dirasakan tidak sebanding dengan kasih sayang yang diberikan kepada kedua kakaknya. Bagi Nisa, kasih sayang orang tua yang memanjakan kedua kakaknya dianggap sangat berlebihan sehingga selalu menimbulkan perselisihan (perlawanan) di antara mereka.

"Dasar pemalas!" katanya sambil mencibir.

"Kau yang pemalas. Kerjanya cuma tidur. Dasar pembohong! Ngomongnya belajar ternyata ngorok!"

"Kau yang pembohong!"

"Kau!"

"Kau!"

"Kau, Kau. Kau, kau...! Teriakku panjang kemudian menutup pintu dengan, ganas. (PBS, hlm. 24)

Sikap Nisa terhadap kedua kakaknya menunjukkan adanya sikap kesal sebagai akibat dari perlakuan yang tidak adil. Membanting pintu kamar menunjukkan bahwa kemarahan Nisa sudah tidak terbendung karena sudah terlampau lama merasakan ketidakadilan. Adalah hal yang biasa jika anak-anak membanting pintu karena berebut mainan dengan kakak atau adiknya. Biasanya,pertengkaran tersebut akan berakhir dan hilang dengan sendirinya atau terlupakan karena berganti dengan keceriaan yang lain dalam bermain. Akan tetapi, bagi Nisa, membanting pintu tersebut bukan hanya soal permainan yang menyenangkan sehingga dapat melupakan peristiwa sebelumnya. Sikap diskriminatifyang tidak semestinya itulah yang tidak dapat diterimanya pada usia yang masih kanak-kanak.

Pada ranah yang lebih luas, kutipan tersebut dapat dikatakan sebagai penegasan bahwa diskriminasi gender, selain dibangun melalui konstruksi sosial yang mapan, juga sudah tumbuh menjadi bangunan ideologi dalam lingkungan sekolah atau pesantren. 
Penanaman sejak awal suatu keyakinan-pekerjaan wilayah domestik-yang harus dipaksakan dan diterima oleh Nisa merupakan doktrin sosial yang sejak lama terjadi dalam rumah. Tujuannya adalah untuk menumbuhkan keyakinan bagi kaum perempuan bahwa setelah dewasa segala pekerjaan dalam wilayah domestik dapat diterima sebagai perintah Tuhan karena disampaikan dalam lingkungan pesantren dan disampaikan oleh kiai.

Sebagaimana peristiwa diskriminasi dan sikap resistansi Nisa sebelumnya, yang disampaikan dalam suasana bercanda, tapi membuat kesal, juga dapat dilihat pada ketipan berikut.

"Sst! Jangan keras-keras kalau ketawa.Kau ini anak perempuan. Tahu?, (PBS, hlm. 34).

"Sst! Jangan pelan-pelan kalau ketawa. Kau ini anak-laki-laki. Tahu? (PBS, hlm. 35).

"Jangan ketawa kecil dan ketawalah yang besar" adalah ironi atas keserakahan laki-laki. Bukankah ketawa yang besar merupakan tanda atau klaim kekuasaan dan kehebatan laki-laki? Oleh kekuasaan laki-laki, perempuan hanya boleh tertawa kecil. Dengan kata lain, laki-laki dapat melakukan apa saja, sementara perempuan harus menerima batasan atas segala bentuk aktivitas yang dilakukan, sekalipun hanya tertawa. Tertawa, juga dapat diartikan sesuatu (benda) yang sederhana, tetapi itupun dibatasi (dirampas). Artinya, tidak ada lagi yang tersisa karena semuanya sudah dimiliki (dirampas) oleh lelaki. Dengan demikian, diskriminasi dan model resistansi pada sejumlah peristiwa yang melibatkan, baik Nisa, Risal, dan Wildan dengan tokoh lain, berfungsi untuk menunjukkan dua hal berikut. Pertama, Nisa melakukan resistansi atas diskriminasi yang menggunakan konsep patriarkal untuk membenarkan segala bentuk diskriminasi. Kedua, menunjukkan model diskriminasi perempuan melalui usia anak-anak, yaitu Wildan, Risal, dan Nisa yang berfungsi untuk menunjukkan kemapanan diskriminasi yang terjadi dalam lingkungan rumah dan sekolah.

\subsection{Resistansi dan Model Resistansi pada Usia Dewasa}

Resistansi dan model resistansi yang digambarkan melalui pemanfaatan usia merupakan rangkaian pola estetik untuk mengukuhkan bahwa peristiwa diskriminasi gender telah terjadi secara masif yang dipolakan dalam lingkungan rumah dan sekolah melalui tahapan perkembangan usia, yaitu usia anak-anak hingga dewasa. Melalui model tahapan perkembangan usia manusia menegaskan bahwa kemapanan diskriminasi merupakan perubahan model penceritaan dari usia anak-anak ke usia remaja atau dewasa.

Dimulai dari pemberian nama, Nisa — bernama asli Annisa Nuhaiyyah yang berarti perempuan yang berakal atau perempuan yang berpandangan luaskelak diharapkan dapat menggantikan posisi ayahnya sebagai pemimpin pesantren dan tokoh masyarakat. Namun, mimpi-mimpi yang dibangun orang tua tidak berhasil. Orang tua merajut cita-citanya kepada Nisa di pesantren dengan menggunakan konsep patriarkal menata kehidupan Nisa di masa datang dalamkehidupan sosial. Sementara itu, Nisa menolak dan melakukan resistansi terhadap doktrin patriarkal yang telah melecehkan dan mendiskreditkan perempuan. Ditinjau dari pemberian nama yang diharapkan jadi pemimpin oleh keluarga (wakil dari lingkungan sosial atau kaum patriarkal), Nisa telah mengalami kegagalan dan telah mengecewakan orang tua. Akan tetapi, sebaliknya, dalam penegakan kesetaran gender, Nisa telah berhasil melakukan perlawanan dan berhasil menjadi pemimpin, setidaknya untuk dirinya sendiri.

Tidak hanya ketidakadilan pada masa anakanak dirasakan Nisa, tetapi juga ketika dewasa. Resistansi, baik dalam bentuk tindakan maupun ujaran yang bersifat ironis, sekaligus menunjukkan sikap Nisa sudah dewasa.

"Bagaimana pendapat ibu tentang ucapan sahabat Nabi itu."

"Orang mengatakan, jika perempuan bakhil, mereka dapat menjaga harta suaminya.Sedang perempuan yang mengagumi diri sendiri umumnya tidak mau berbicara dengan laki-laki lain dengan kata-kata yang halus yang menimbulkan kecurigaan suaminya dan jika mereka penakut, mereka tidak berani keluar rumah yang menimbulkan kecurigaan suaminya. Itulah yang dimaksud dengan ucapan sahabat di atas."

"Maksud Nisa, apa bakhil dan tidak bersedekah itu baik dimata Allah? Dan mengagumi diri sendiri 
itu bukankah riya?Bukankah sifat dermawan itu dianjurkan.Rendah hati dan keberanian di jalan kebenaran itu juga terpuji. Mengapa jika perempuan, semuanya jadi terbalik?" (PBS, hlm. 75).

Peristiwa diskusi antara Nisa dan ibunya, setidaknya menunjukkan dua hal. Pertama, kesahihan hadis itu sendiri. Kedua, Nisa makin kritis sehingga selalu mempertanyakan sesuatu yang bersifat diskriminatif. Mencermati peristiwa ini, oleh Nisa, diduga banyak hadis yang ditafsirkan hanya untuk kepentingan dan melanggengkan kepentingan laki-laki. Dengan segala yang dirasakannya, Nisa mencoba mendiskusikan dan berusaha menegaskan kepada ibunya, bahwa tidak semua hadis yang ditafsirkan bertujuan memajukan dan mencerdaskan penganut agama Islam. Sikap ini digambarkan melalui penggalan pertanyaan "mengapa jika perempuan, semuanya jadi terbalik?", tetapibisa juga untuk kepentingan yang lain (patriarkal). Dalam penegasan yang lain bahwa mengapa perbuatan yang baik dianjurkan, dan seolah-olah hanya untuk kaum laki-laki, sedangkan bagi perempuan semuanya kelihatan serba terbalik, yang buruk saja.

Kutipan berikutnya yang menunjukkan model resitensi Nisa dapat dilihat pada kutipan berikut.

"Perempuan mana saja yang diajak suaminya untuk berjimak lalu ia menunda-nunda hingga suaminya tertidur, maka ia akan dilaknat oleh Allah. "Kemudian lanjutnya," perempuan mana saja yang cemberut di hadapan suaminya, maka dia dimurkahi Allah sampai ia dapat menimbulkan senyuman suaminya dan meminta keridhaannya (PBS, hlm. 79-80).

"Bagaimana jika istrinya yang mengajak ke tempat tidur dan suami menunda-nunda hingga istri tertidur. Apa suami juga dilaknat Allah, Pak Kiai?” (PBS, hlm. 80).

Kurang lebih sama peristiwa ini dangan hadis yang didiskusikan Nisa dengan ibunya pada peristiwa sebelumnya. Yang berbeda hanya teman diskusi dan tempat. Sekarang yang menjadi tempat bertanya Nisa adalah Kiai Ali dan berada di tempat formal, ruang kelas. Peristiwa ini menunjukkan bahwa sekolah hanya menjadi tempat pemandaian akal, tanpa dapat menjadi tempat bertumbuhnya kesadaran kehidupan yang berkesetaraan gender yang merupakan perintah Tuhan yang mewajibkan kepada lembaga atau siapapun untuk berlaku adil. Sekolah dan rumah hanya menjadi tempat pengukuhan doktrinitas patriarkat (kuatnya kekuasaan laki-laki). Pertanyaan Nisa justru dikukuhkan dan hanya dianggap sebagai perpanjangan kaum kafir yang akan meruntuhkan Islam. Sebagaimana pada penjelasan sebelumnya, pada konteks ini agama juga dimanfaatkan sebagai tempat berlindung budaya patriarkat. Oleh karena itu, segala pengetahuan ilmu agama yang diajarkan oleh Kiai harus diterima secara absolut, tanpa harus dilacak sumber kebenarannya dan diketahui pada konteks bagaimana suatu hadis muncul dimasa Nabi dan kemudian dijadikan sumber kebenaran. Sebagai sumber kebenaran dari Tuhan, tentu hadis tidak ada yang diskriminatif.

Diskriminasi gender juga dialami Nisa dalam rumah tangga. Seperti bentuk diskriminasi sebelumnya, Nisa tidak dapat menerima perlakuan yang melecehkan dirinya (perempuan), sekalipun yang melakukan adalah Syamsudin, suaminya. Hal tersebut dapat dilihat pada kutipan berikut.

"Hentikan kelakuanmu! Atau aku pergi dari rumah ini."

"Waduh, waduh! Galak amat!" Ia tertawa dan terus tertawa melecehkan.

"Kau pikir karena kau suamiku, kau bisa seenaknya memperlakukan aku?"

"Apa yang kau katakana Nisa? Aku hanya ingin main-main denganmu."

"Main-main? Permainanmu sangat menyebalkan." "Oh, yang mana lebih menyebalkan, permainanku atau nada bicaramu."

"Kita lihat saja Nanti".

.."Kau memperkosaku, Samsuddin! Kau telah memperkosaku!"

"Memperkosa? Heh...," ia terbahak-bahak kecil karena puas mengerjaiku". Mana ada suami memperkosa istri sendiri, kau ini aneh Nisa.Aku belum pernah melihat perempuan sebodoh kamu ini.Tetapi sekalipun bodoh, kau begitu molek. Tubuhmu begitu luar biasa, heh heh heh..."

"Hentikan ocehanmu! Perilakumu seperti bukan muslim!" 
"Oh, ya, tahu apa kau tentang muslim, istriku sayang?” (PBS, hlm.96--97)

Dari sejumlah peristiwa sebelumnya, peristiwa ini menegaskan bahwa dalam berbagai kehidupan perempuan selalu menjadi korban pelecehan lakilaki. Perempuan yang sudah diikat dengan tali perkawinan membangun kesadaran legetimasi bagi suami untuk dapat melakukan apa saja terhadap istrinya. Oleh sebab itu, tidak jarang suami (laki-laki) melakukan tindakan yang tidak menyenangkan terhadap istrinya (perempuan). Padahal, pada saat yang sama dengan perlakuan itu laki-laki telah melecehkan dan merendahkan perempuan.

Sejumlah peristiwa yang dialami Nisa pada usia dewasa merupakan kelanjutan sikap resistansi dari usia anak-anak yang memiliki pola yang sama. $\mathrm{Hu}-$ bungan ini merupakan bangunan struktur yang tidak terpisahkan dengan usia anak-anak dengan usia dewasa karena menjadi sarana estetik untuk menjembatani terbentuknya model. Hanya saja, struktur pengisahan Nisa pada usia dewasa bertujuan untuk menujukkan kemapanan pola konspirasi konstruksi sosial yang digambarkan melalui cara berpikir orang dewasa dalam memecahkan masalah agama yang lebih rumit.

\section{Simpulan}

Model resistansi dan kesetaraan gender dalam PBS dikonstruksi melalui tahapan perkembangan usia yang dibangun lewat usia tokoh, yaitu ketika Nisa, Wildan, dan Risal masih kanak-kanak, remaja, hingga dewasa. Resistansi dan model resistansi perempuan dalam novel PBS merupakan peristiwa diskriminasi gender yang telah terjadi secara masif dalam lingkungan rumah dan sekolah. Model konstruksi sosial dibangun melalui sarana simbol pendidikan agama. Sementara itu, pemanfaatan simbol agama menjadi tempat berlindung untuk pemerolehan legalitas agar diskriminasi tetap mapan dalam berbagai ranah kehidupan. Dalam konteks ini, pesantren telah digerogoti (dijadikan) sebagai tempat mengukuhkan dan berlindungnya kelanggengan budaya patriarkal.
Pada usia dewasa, perjalanan kehidupan Nisa akhirnya menjadi model kesetaraan gender yang diidealkan, yakni melalui perkawinan kedua dengan Lek Khodori. Perkawinan ini merupakan bentuk resistansiterhadap perkawinan pertama Nisa.

\section{Daftar Pustaka}

Djajanegara, Soenarjati. 2000. Kritik Sastra Feminis: Sebuah Pengantar. Jakarta: Gramedia Pustaka Utama.

Endraswara, Suwardi. 2008. Metode Penelitian Sastra: Epistemelogi, Model, Teori, dan Aplikasi. Yogyakarta: Med Press.

Fakih, Mansour. 2001. Analisis Gender dan Transformasi Sosial. Yogyakarta: Pustaka Pelajar.

Fanani, Zainuddin. 2001. Telaah Sastra. Surakarta: Muhammadiyah Press.

Kadarusman. 2005. Agama, Relasi Gender, dan Feminisme. Yogyakarta: Kreasi Wacana.

Drajat. 2003. Citra Perempuan dalam Islam, Pandangan Ormas Keagamaan. Jakarta: Gramedia Pustaka

Ratna, Nyoman Kutha. 2004. Metode dan Teknik Penelitian Sastra. Yogyakarta: Pustaka Pelajar ..... 2003. Paradigma Sosiologi Sastra. Yogyakarta: Pustaka Pelajar

Suharto, Sugiharto. 2005. Kritik Sastra Feminis: Teori dan Aplikasi. Yogyakarta: Pustaka Pelajar.

Sofia, Adib. 2009. Aplikasi Kritik Sastra Feminis: Perempuan dalam Karya-Karya Kuntowijoyo. Yogyakarta: Citra Pustaka.

Teeuw. 1984. Sastra dan Ilmu Sastra: Pengantar Teori Sastra. Jakarta: Pustaka Jaya. 